\title{
Desain Amphibious Dredger untuk Pengerukan Sungai Porong Sidoarjo di Daerah Buangan Lumpur Lapindo
}

\author{
Aufa Dzulfikar Majid dan Hesty Anita Kurniawati \\ Departemen Teknik Perkapalan, Fakultas Teknologi Kelautan, Institut Teknologi Sepuluh Nopember (ITS) \\ e-mail: tita@na.its.ac.id
}

\begin{abstract}
Abstrak-Kali Porong merupakan terusan sungai Kali Brantas (Floodway) yang berhulu di Kota Mojokerto (Bendung Lengkong Baru), mengalir ke arah timur dan bermuara di Selat Jawa. Sungai ini membatasi Kabupaten Sidoarjo dan Kabupaten Pasuruan. Dengan terjadinya bencana Lumpur Sidoarjo pada 30 Mei 2006 dan kemudian pada November 2006 pemerintah menetapkan bahwa Kali Porong sebagai tempat pembuangan Lumpur Sidoarjo menuju ke laut, maka fungsi Kali Porong selain sebagai floodway, juga berfungsi sebagai saluran yang mengalirkan endapan lumpur ke muara. Namun tidak semua endapan lumpur dari buangan Lumpur Lapindo terbawa sampai ke laut. Endapan yang tertinggal dapat menyebabkan pendangkalan Sungai Porong maka perlu dilakukan pengerukan sungai. Jurnal ini mempunyai tujuan untuk melakukan analisis secara teknis mengenai desain kapal yang cocok untuk karakteristik Sungai Porong. Kapal keruk yang digunakan adalah jenis Amphibious Dredger karena sangat cocok dengan struktur geometris sungai. Dipilih kapal jenis tongkang yang mempunyai stabilitas yang baik. Terdiri dari dua kapal yang mempunyai tugas masing-masing, kapal pengangkut muatan yang dilengkapi peralatan amphibi untuk mengangkut sedimen hasil pengerukan dan kapal pengeruk yang dilengkapi backhoe module. Proses desain kapal menentukan payload untuk mendapatkan ukuran utama kapal awal kemudian dilakukan perhitungan analisis teknis menggunakan metode 256 untuk mendapatkan ukuran utama kapal yang paling efektif. Hasil perhitungan teknis diperoleh ukuran utama untuk kapal pengangkut muatan sebesar $\mathrm{Lwl}=11,83 \mathrm{~m}, \mathrm{Lpp}=11,38 \mathrm{~m}, \mathrm{~B}=$ $7,08 \mathrm{~m}, \mathrm{~T}=1,99 \mathrm{~m}, \mathrm{H}=3,38 \mathrm{~m}$. Lalu untuk kapal pengeruk sebesar $\mathrm{Lwl}=8,9 \mathrm{~m}, \mathrm{Lpp}=8,53 \mathrm{~m}, \mathrm{~B}=4,85 \mathrm{~m}, \mathrm{~T}=1,44 \mathrm{~m}, \mathrm{H}=$ $2,12 \mathrm{~m}$ dengan estimasi biaya pembangunan sebesar Rp2.867.136.313,32.
\end{abstract}

Kata Kunci-Amphibious Dredger, Lumpur Lapindo, Sungai Porong,

\section{PENDAHULUAN}

$S^{\text {nim }}$ DOARJO memiliki sungai Porong yang merupakan terusan sungai Kali Brantas (Floodway) yang berhulu di Kota Mojokerto (Bendung Lengkong Baru), mengalir ke arah timur dan bermuara di Selat Jawa. Kali Porong berada di dekat lokasi dimana semburan lumpur Sidoarjo. Dengan volume semburan lumpur Lapindo yang mencapai $\pm 126.000 \mathrm{~m}^{3} /$ hari, dikhawatirkan akan mengalami pendangkalan akibat lumpur Sidoarjo.

Dari masalah tersebut dapat dilakukan solusi yang tepat dengan melakukan pengerukan sungai. Oleh karena itu, penulis mencoba mendesain kapal keruk yang cocok, khusus, dan tepat guna untuk operasi Sungai Porong saat ini. Selain itu pada penelitian ini dilakukan penambahan penggunaan chainwheel pada kapal sehingga kapal dapat pula beroperasi di darat. Hal tersebut bertujuan agar kapal dapat digunakan di sungai lain yang memiliki karakteristik dan jenis sedimen yang sama dengan Sungai Porong. Jenis Alat keruk yang digunakan pada kapal Amphibi Dredger ini adalah Backhoe karena melihat lingkungan sekitar Sungai Porong kawasan ramai.

\section{TINJAUAN PUSTAKA}

\section{A. Sungai Porong}

Kali Porong merupakan terusan sungai Kali Brantas (Floodway) yang berhulu di Kota Mojokerto (Bendung Lengkong Baru) Kali Porong mempunyai dua anak sungai yaitu Kali Sedat (KP. 100) dengan luas DAS 406,7 $\mathrm{Km}^{2}$ dan Kali Kambing (KP. 148) dengan luas DAS 196,6 $\mathrm{Km}^{2}$. Dengan terjadinya bencana Lumpur Sidoarjo tahun 2006 dan kemudian pada November 2006 pemerintah menetapkan bahwa Kali Porong sebagai tempat pembuangan Lumpur Sidoarjo menuju ke laut, maka fungsi Kali Porong selain sebagai floodway, juga berfungsi sebagai saluran yang mengalirkan endapan lumpur ke muara [1].

\section{B. Backhoe dredger}

Backhoe/dipper dredger memiliki sebuah backhoe seperti excavator. Backhoe dredger dapat pula menggunakan excavator untuk darat, diletakkan di atas tongkang. Biasanya backhoe dredger ini memiliki tiga buah spudcan, yaitu tiang yang berguna sebagai pengganti jangkar agar kapal tidak bergerak, dan pada backhoe dredger yang high-tech, hanya memerlukan satu orang untuk mengoperasikannya. Lengan tersebut digerakan dengan sistem hidrolik. Backhoe Dredger sangat cocok digunakan untuk wilayah perairan yang dangkal. Selain itu, kapal keruk jenis ini cocok jika dioperasikan untuk wilayah yang memiliki karakteristik material keruk yang berpasir, berbatu, atau campuran antara keduanya [2].

\section{Kendaraan Amphibi}

Pengertian kendaraan amfibi adalah kendaraan yang dapat beroprasi di dua alam, khusus darat dan perairan. Ditemukan inovasi, salah satunya adalah kendaraan amfibi. Kendaraan 
amfibi diduga muncul pada pertengahan tahun 1800, ketika itu orang amerika yang bernama Oliver Evans menciptakan sebuah alat bertenaga uap yang berhasil dioperasikan lebih dari satu mil dijalan-jalan philadelphia dan berlayar di sungai delaware. Kendaraan itu disebut Orukter Amphibolus dan menjadi amfibi pertama dari mesin uap [3].

\section{Chainwheel}

Chainwheel adalah sistem pergerakan kendaraan dengan menggunakan sabuk kontinu yang dikendalikan oleh dua atau lebih roda. Sabuk ini umumnya dibuat dari baja untuk penggunaannya di kendaraan militer, atau karet yang diperkuat dengan kawat baja untuk aplikasi alat berat konstruksi dan pertanian. Luas bidang permukaan yang besar dari roda rantai membagi berat kendaraan lebih baik daripada kendaraan beroda, sehingga memungkinkan kendaraan roda rantai bergerak di atas permukaan yang lebih lunak dan menghindari kemungkinan roda terjebak. [4].

\section{E. Zoning}

Zoning dilakukan dengan cara melakukan survei lapangan secara langsung untuk melihat kondisi pembuangan lumpur Lapindo di Sungai Porong. Setelah dilakukan pengamatan, sejauh $16 \mathrm{~km}$ dari titik pintu pembuangan lumpur sampai hulu Sungai Porong.

Pemilihan rute operasional Amphibious Dredger ini dilakukan dengan cara melihat hasil dari hasil zoning yang sudah dilakukan. Berdasarkan pendangkalan di Sungai Porong sejauh $16 \mathrm{~km}$, maka pada zona itu ditetapkan sebagai daerah operasional pengerukan. Telah ditentukan ilustrasi rute,rute operasional yang dipilih yaitu mulai dari Pejarakan, Jabon, Sidoarjo sampai Tambak Kalisongo, Jabon, Sidoarjo. Rute operasional dapat dilihat pada Gambar 1.

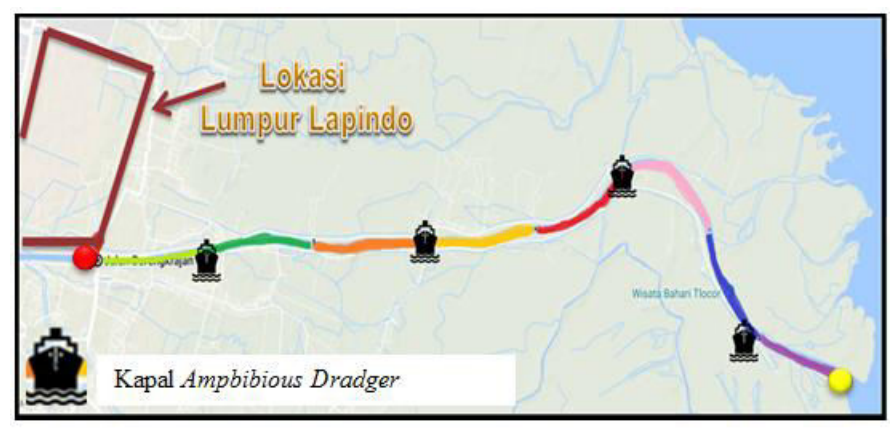

- Lokasi awal operasi pengerukan

Lokasi akhir operasi pengerukan

Gambar 1. Péta Rencana Operasi Drēger Ämphibious.

\section{METODOLOGI PENELITIAN}

\section{A. Uтит}

Pada tahap metode, pendahuluan merupakan langkah awal dalam pelaksanaan penelitian. Tahap pendahuluan merupakan tahap yang sangat penting dimana pada tahap ini penetapan tujuan dan pengidentifikasian permasalahan dilakukan.

\section{B. Studi Literatur}

Studi literatur dilakukan dalam melaksanakan penilitian jurnal ini yang berkaitan dengan permasalahan yang ada serta mencari informasi dan referensi yang mendukung dalam menyelesaikan masalah mendesain kapal kerja ini. Studi literatur yang dilakukan adalah yang berkaitan dengan pemahaman teori dan konsep dari perhitungan stabilitas, trim, freeboard maupun perhitungan berat total kapal.

\section{Pencarian Data}

Dalam menyelesaikan jurnal ini, ada dua jenis data yang digunakan yaitu Primer dan Sekunder:

- Data primer, diperoleh dari pengamatan langsung di Sungai Porong sebagai wilayah operasional kapal dan wawancara langsung dengan beberapa pihak yang memiliki kepentingan dan permasalahan dengan Sungai Porong.

- Data sekunder, diperoleh dari berbagai literatur, paper, buku dan internet serta data mengenai kondisi alam di wilayah yang menjadi objek penelitian. Dalam hal ini data untuk karakteristik Sungai Porong diperoleh dari Balai Besar Wilayah Sungai Brantas Surabaya yang meliputi, kedalaman sungai dan lebar minimum.

\section{Pengolahan Data}

Setelah data yang dibutuhkan untuk mendesain sudah diperoleh, langkah selanjutnya adalah mengolah data tersebut sehingga menghasilkan desain yang memenuhi syarat permintaan owner kapal atau sesuai dengan tujuan dibangunnya Amphibious Dredger.

\section{ANALISIS TEKNIS DAN PERHITUNGAN EKONOMIS}

\section{A. Analisis Teknis}

\section{1). Perhitungan Payload}

Perhitungan Payload pada Amphibious Dredger didasarkan pada struktur geometris Sungai Porong yang meliputi kedalaman sungai, lebar minimum sungai, keadaan lingkungan saat menuju daratan dan volume sedimentasi. Datadata tersebut juga digunakan untuk menentukan Operational Requirements kapal. Data lapangan mengenai kondisi Sungai Porong tersaji pada Tabel 1.

Tabel 1.

Rekapitulasi Perhitungan Payload

\begin{tabular}{cc}
\hline \hline Data Yang Dibutuhkan & Nilai \\
\hline Jarak Lintasan Keruk & $16000 \mathrm{~m}$ \\
Lebar Minimum Sungai & $48 \mathrm{~m}$ \\
Tinggi Sedimentasi Sungai & $1 \mathrm{~m}$ \\
Volume Keruk & $768000 \mathrm{~m}^{3}$ \\
Rencana Waktu & $368 \mathrm{hari}$ \\
Pengerukan & \\
Volume Pengangkutan & 2104.11 \\
& $\mathrm{~m}^{3} / \mathrm{hari}$ \\
Data Yang Dibutuhkan & Nilai \\
Estimasi Pengangkutan & $4 \mathrm{kali} / \mathrm{hari}$ \\
Berat Muatan & 49.1 ton \\
Massa Jenis Lumpur & 0,746 ton $/ \mathrm{m}^{3}$ \\
\hline \hline
\end{tabular}




\section{2) Penentuan Ukuran Utama}

Untuk mendapatkan ukuran utama kapal adalah dengan mengoptimisasi ukuran utama awal kapal menggunakan metode 256. Hasil metode 256 dapat dilihat pada Tabel 2.

Tabel 2.

\begin{tabular}{|c|c|c|c|c|}
\hline \multirow[t]{2}{*}{ Item } & \multicolumn{2}{|c|}{$\begin{array}{c}\text { Pengangkut } \\
\text { muatan }\end{array}$} & \multicolumn{2}{|c|}{$\begin{array}{c}\text { Kapal } \\
\text { Backhoe }\end{array}$} \\
\hline & Value & Unit & Value & Unit \\
\hline $\mathrm{L}_{W L}$ & 11,83 & $\mathrm{~m}$ & 8,9 & $\mathrm{~m}$ \\
\hline B & 7,08 & $\mathrm{~m}$ & 4,85 & $\mathrm{~m}$ \\
\hline $\mathrm{T}$ & 1,99 & $\mathrm{~m}$ & 1,44 & $\mathrm{~m}$ \\
\hline $\mathrm{H}$ & 3,38 & $\mathrm{~m}$ & 2,12 & $\mathrm{~m}$ \\
\hline
\end{tabular}

\section{3). Perhitungan Freeboard, Trim, dan Stabilitas}

Untuk perhitungan Freeboard, Trim, dan Stabilitas, digunakan standar-standar yang berlaku sesuai yang diisyaratakan, Tabel 3, Tabel 4 dan Tabel 5 adalah rekapitulasi perhitungan Freeboard, Trim dan Stabilitas:

Tabel 3.

Rekapitulasi Perhitungan Trim

\begin{tabular}{clccc}
\hline \hline No & Kapal Pengangkut Muatan & Value & Kriteria & Status \\
\hline 1 & Freeboard & $1.32 \mathrm{~m}$ & $0,917 \mathrm{~m}$ & OK \\
& (KR) Korean Regrestation. & $-0,052 \mathrm{~m}$ & 0,057 & OK \\
2 & Trim Kondisi 100\% & $-0,037 \mathrm{~m}$ & 0,057 & OK \\
& Trim Kondisi 75\% & $0,037 \mathrm{~m}$ & 0,057 & OK \\
& Trim Kondisi 50\% & $0.043 \mathrm{~m}$ & 0,057 & OK \\
& Trim Kondisi 25\% & $0.05 \mathrm{~m}$ & 0,057 & OK \\
& Trim Kondisi Kosong
\end{tabular}

Tabel 4.

Rekapitulasi Perhitungan Trim

\begin{tabular}{clccc}
\hline \hline No & \multicolumn{1}{c}{ Kapal Backhoe } & Value & Kriteria & Status \\
\hline 1 & Freeboard & $0,68 \mathrm{~m}$ & $0,56 \mathrm{~m}$ & OK \\
& (KR) Korean Regrestation. & $0.041 \mathrm{~m}$ & $0.0445 \mathrm{~m}$ & OK \\
& Trim Kondisi 100\% & $0.027 \mathrm{~m}$ & $0.0445 \mathrm{~m}$ & OK \\
& Trim Kondisi 75\% & $0,021 \mathrm{~m}$ & $0.0445 \mathrm{~m}$ & OK \\
& Trim Kondisi 50\% & $0.015 \mathrm{~m}$ & $0.0445 \mathrm{~m}$ & OK \\
& Trim Kondisi 25\% & $0,007 \mathrm{~m}$ & $0.0445 \mathrm{~m}$ & OK \\
& Trim Kondisi Kosong & & &
\end{tabular}

Tabel 5.

Rekapitulasi Perhitungan Stabilitas

\begin{tabular}{|c|c|c|c|c|c|}
\hline \multirow{2}{*}{$\begin{array}{c}\text { Kriteria Pengangkut } \\
\text { Muatan }\end{array}$} & \multicolumn{5}{|c|}{ Kondisi } \\
\hline & $100 \%$ & $75 \%$ & $50 \%$ & $25 \%$ & $0 \%$ \\
\hline \multirow{2}{*}{$\mathrm{A} \theta(0-30) \geq 3,151$} & 19,26 & 21,5 & 24,4 & 28,2 & 31,1 \\
\hline & 5 & 8 & 8 & 6 & 5 \\
\hline \multirow{2}{*}{$\mathrm{A} \theta(0-40) \geq 5,156$} & 32,23 & 35,6 & 39,6 & 44,7 & 48,5 \\
\hline & 5 & 8 & 7 & 3 & 8 \\
\hline \multirow{2}{*}{$\mathrm{A} \theta(30-40) \geq 1,718$} & \multirow{2}{*}{12.97} & 14,0 & 15,1 & 16,4 & 17,4 \\
\hline & & 9 & 9 & 7 & 2 \\
\hline \multirow{2}{*}{$\mathrm{GZ} \theta 30 \geq 0,2$} & \multirow{2}{*}{1,317} & \multirow{2}{*}{1,44} & 1,55 & 1,68 & 1,76 \\
\hline & & & 9 & 3 & 8 \\
\hline \multirow{2}{*}{$\theta \mathrm{GZ} \max \geq 25^{\circ}$} & \multirow{2}{*}{38,20} & 38,6 & 40,5 & 42,3 & 41,8 \\
\hline & & 0 & 0 & 0 & 0 \\
\hline \multirow{2}{*}{ InitialGMt $\geq 0,15$} & \multirow{2}{*}{2,244} & 2,76 & 3,20 & 3,85 & 4,39 \\
\hline & & 5 & 8 & 1 & 1 \\
\hline Wind and rolling $<16$ & 3,70 & 3,90 & 40 & 4,10 & 4,20 \\
\hline \multirow{2}{*}{$G Z$ : to Max $G Z>4,58$} & 29,84 & 33,7 & 40,3 & 48,5 & 51,7 \\
\hline & 2 & 1 & 8 & 6 & 9 \\
\hline Angle of equilibrium $<50 \%$ & $0 \%$ & $0 \%$ & $0 \%$ & $0 \%$ & $0 \%$ \\
\hline Status & $\mathrm{OK}$ & $\mathrm{OK}$ & $\mathrm{OK}$ & $\mathrm{OK}$ & OK \\
\hline \multirow[t]{2}{*}{ Kriteria Kapal Backhoe } & \multicolumn{5}{|c|}{ Kondisi } \\
\hline & $100 \%$ & $75 \%$ & $50 \%$ & $25 \%$ & $0 \%$ \\
\hline $\mathrm{A} \theta(0-30) \geq 3,151$ & 9,421 & 9,50 & 9,52 & 9,52 & 9,55 \\
\hline
\end{tabular}

\begin{tabular}{|c|c|c|c|c|c|}
\hline & & 2 & 2 & 7 & 5 \\
\hline \multirow{2}{*}{$\mathrm{A} \theta(0-40) \geq 5,156$} & 15,43 & 15,5 & 15,6 & 15,6 & 15,6 \\
\hline & 6 & 9 & 3 & 4 & 9 \\
\hline \multirow{2}{*}{$\mathrm{A} \theta(30-40) \geq 1,718$} & \multirow{2}{*}{6,014} & 6,09 & 6,11 & 6,11 & 6,14 \\
\hline & & 0 & 4 & 6 & 2 \\
\hline $\mathrm{GZ} \theta 30 \geq 0,2$ & 0,611 & $\begin{array}{c}0,61 \\
8\end{array}$ & 0,62 & 0,62 & $\begin{array}{c}0,62 \\
3\end{array}$ \\
\hline$\theta \mathrm{GZmax} \geq 25^{\circ}$ & $38,2^{0}$ & $38,2^{0}$ & $38,2^{0}$ & $38,2^{0}$ & $37,7^{0}$ \\
\hline \multirow{2}{*}{ InitialGMt $\geq 0,15$} & \multirow{2}{*}{1,194} & \multirow{2}{*}{1,2} & 1,20 & 1,20 & 1,20 \\
\hline & & & 1 & 1 & 3 \\
\hline Wind and rolling $<16$ & $13,3^{0}$ & $13,3^{0}$ & $13,4^{0}$ & $13,4^{0}$ & $13,4^{0}$ \\
\hline \multirow{2}{*}{$G Z$ : to $\operatorname{Max} G Z>4,58$} & 14,32 & 14,4 & 14,5 & 14,5 & 14,2 \\
\hline & 6 & 7 & 0 & 1 & 8 \\
\hline Angle of equilibrium $<50 \%$ & $0 \%$ & $0 \%$ & $0 \%$ & $0 \%$ & $0 \%$ \\
\hline Status & OK & $\mathrm{OK}$ & $\mathrm{OK}$ & $\mathrm{OK}$ & $\mathrm{OK}$ \\
\hline
\end{tabular}

4). Rencana Garis

Rencana Garis adalah gambar proyeksi badan kapal yang dipotong secara melintang (body plan), secara memanjang (sheer plan), dan vetikal memanjang (half breadth plan). Proses pembuatan desain rencana garis dimulai setelah ukuran utama kapal diketahui. Adapun desain Rencana Garis ini dapat dilihat pada Gambar 2.

5). Rencana Umum

Rencana Umum dari kapal kerja dapat didesain setelah Rencana Garis selesai. Rencana Umum adalah perencanaan ruangan pada kapal, yang disesuaikan dengan fungsi, kebutuhan dan perlengkapan kapal. Rencana Umum dari kapal kerja ini dapat dilihat pada Gambar 3.

\section{6). Desain 3D Model}

Dari hasil desain rencana umum yang sudah dibuat pada Gambar 3, maka dilanjutkan dengan pembuatan atau desain 3 dimensi. Untuk desain 3 dimensi dapat dilihat pada Gambar 3.

\section{B. Perhitungan Ekonomis}

Proses menghitung biaya pembangunan kapal ini berdasarkan komponen-komponen apa saja yang direncanakan terdapat di kapal. Kemudian mulai mencari harga pasaran dari komponen-komponen tersebut [5]. Komponen-komponen yang dihitung antara lain harga pelat kapal, square piles, Backhoe, main engine, generator set, dan elektroda las. Dari komponen-komponen tersebut, total biaya pembangunan kapal (buliding cost) pengangkut muatan dan kapal Backhoe yang diperoleh sebesar Rp2.867.136.313,32.

\section{KESIMPULAN}

Setelah melalui berbagai tahapan desain dan juga analisis perhitungan teknis beserta ekonomisnya, maka dari jurnal ini bisa ditarik beberapa kesimpulan sebagai berikut:

1. Dari hasil analisis perhitungan kapasitas muatan keruk, diperoleh besar kapasitas muatan keruk yang dapat ditampung oleh kapal (Payload) sebesar 49,1 ton.

2. Dari hasil analisis yang telah dilakukan, diperoleh ukuran utama Amphibious Dredger sebagai berikut:

Kapal Pengangkut muatan 
- Length of Waterline (Lwl) $=11,83 \mathrm{~m}$

- Length Between Perpendicular $(\mathrm{Lpp})=11,38 \mathrm{~m}$

- $\operatorname{Breadth}(\mathrm{B}) \quad=7,08 \mathrm{~m}$

- $\operatorname{Height}(\mathrm{H}) \quad=3,38 \mathrm{~m}$

- $\operatorname{Draught}(\mathrm{T}) \quad=1,99 \mathrm{~m}$

Kapal Backhoe

- Length of Waterline (Lwl) = $8,9 \mathrm{~m}$

- Length Between Perpendicular $(\mathrm{Lpp})=8,53 \mathrm{~m}$

- Breadth $(\mathrm{B})=4,85 \mathrm{~m}$
- Height $(\mathrm{H})$

$=2,12 \mathrm{~m}$

- Draught (T)

$=1,44 \mathrm{~m}$

3. Hasil perhitungan stabilitas, freeboard dan trim dinyatakan memenuhi dan hasil detail dapat dilihat pada Lampiran A

4. Dari hasil perhitungan Building Cost yang telah dilakukan, diperoleh harga biaya pembangunan kapal sebesar Rp2.867.136.313,32.
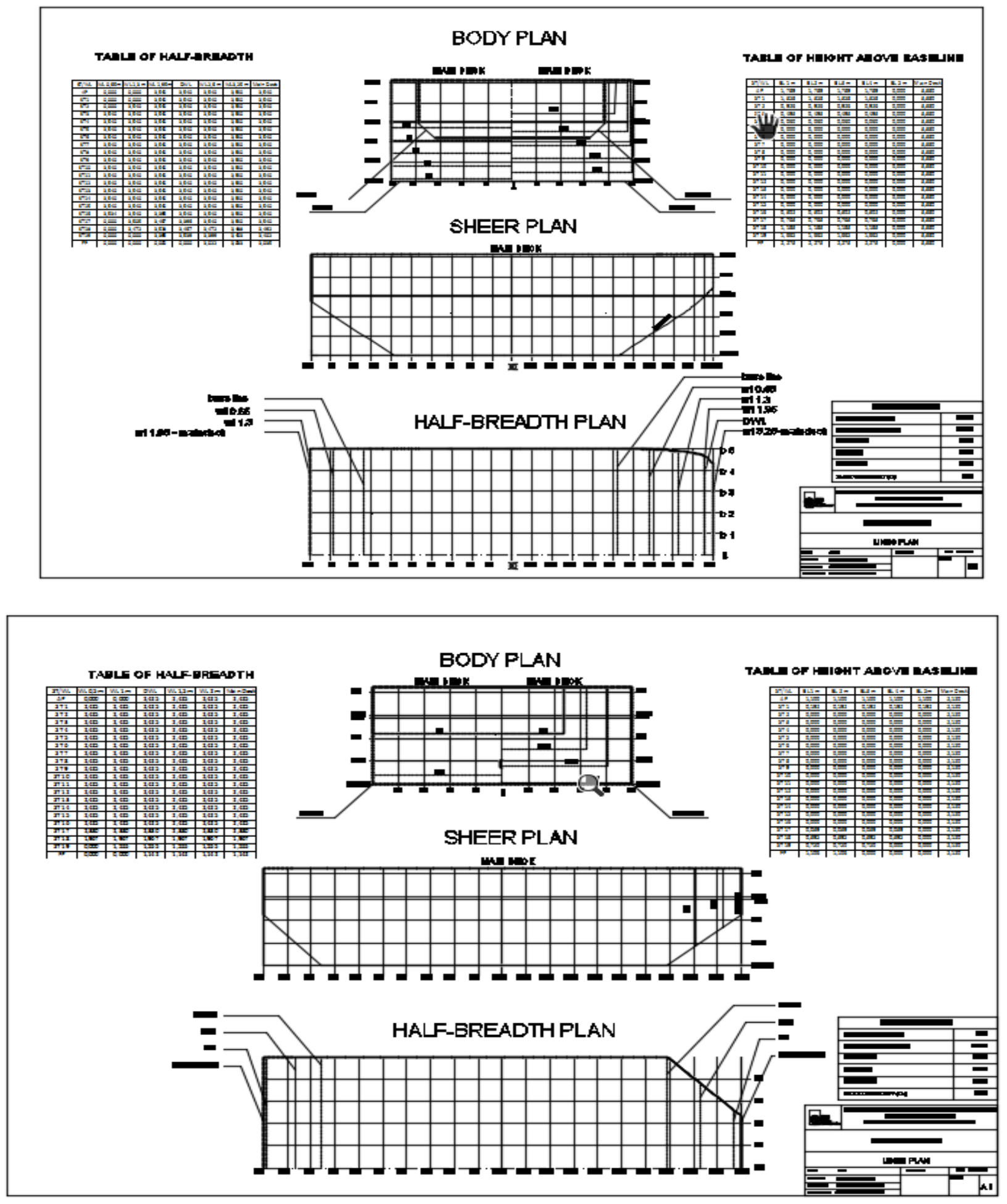

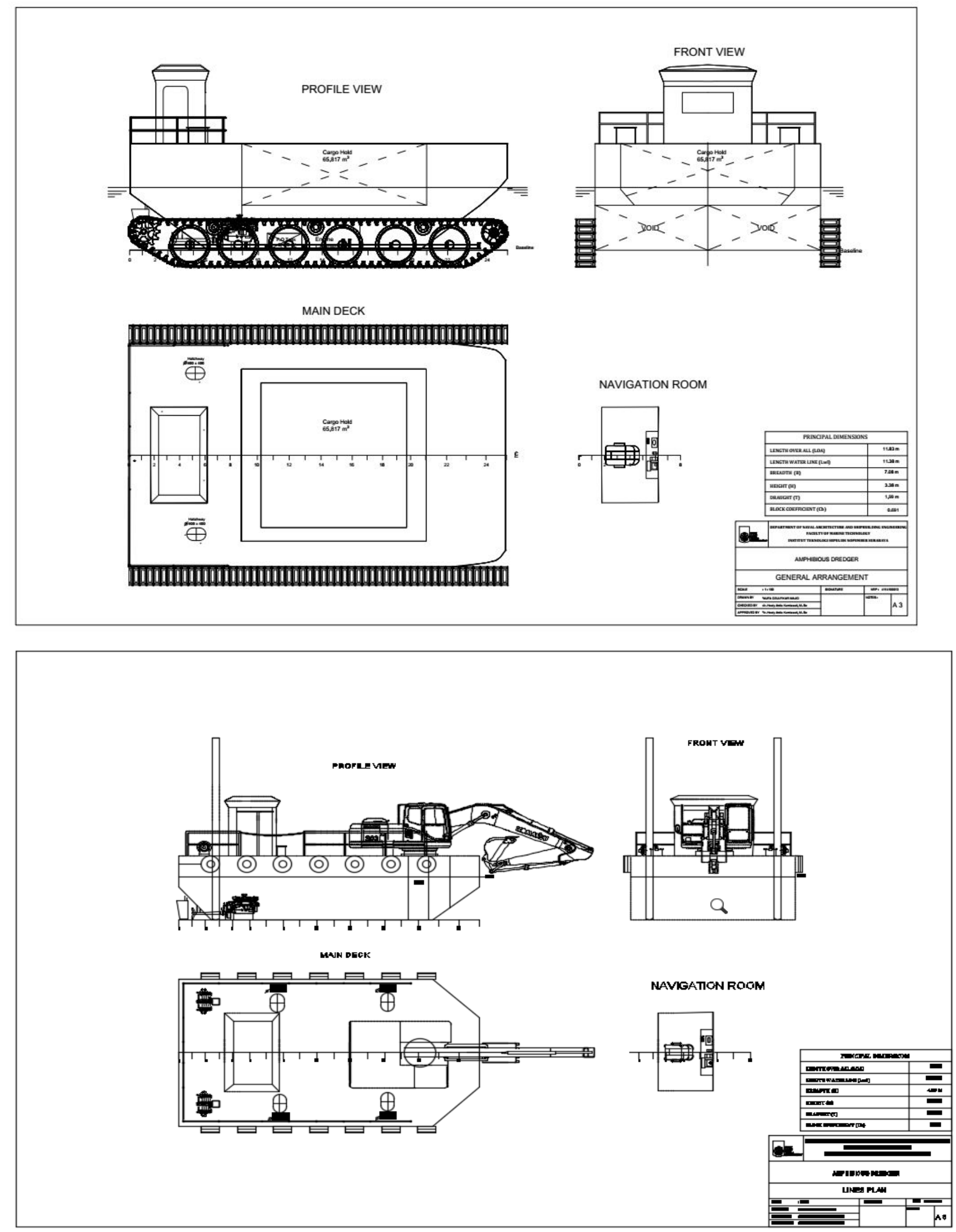


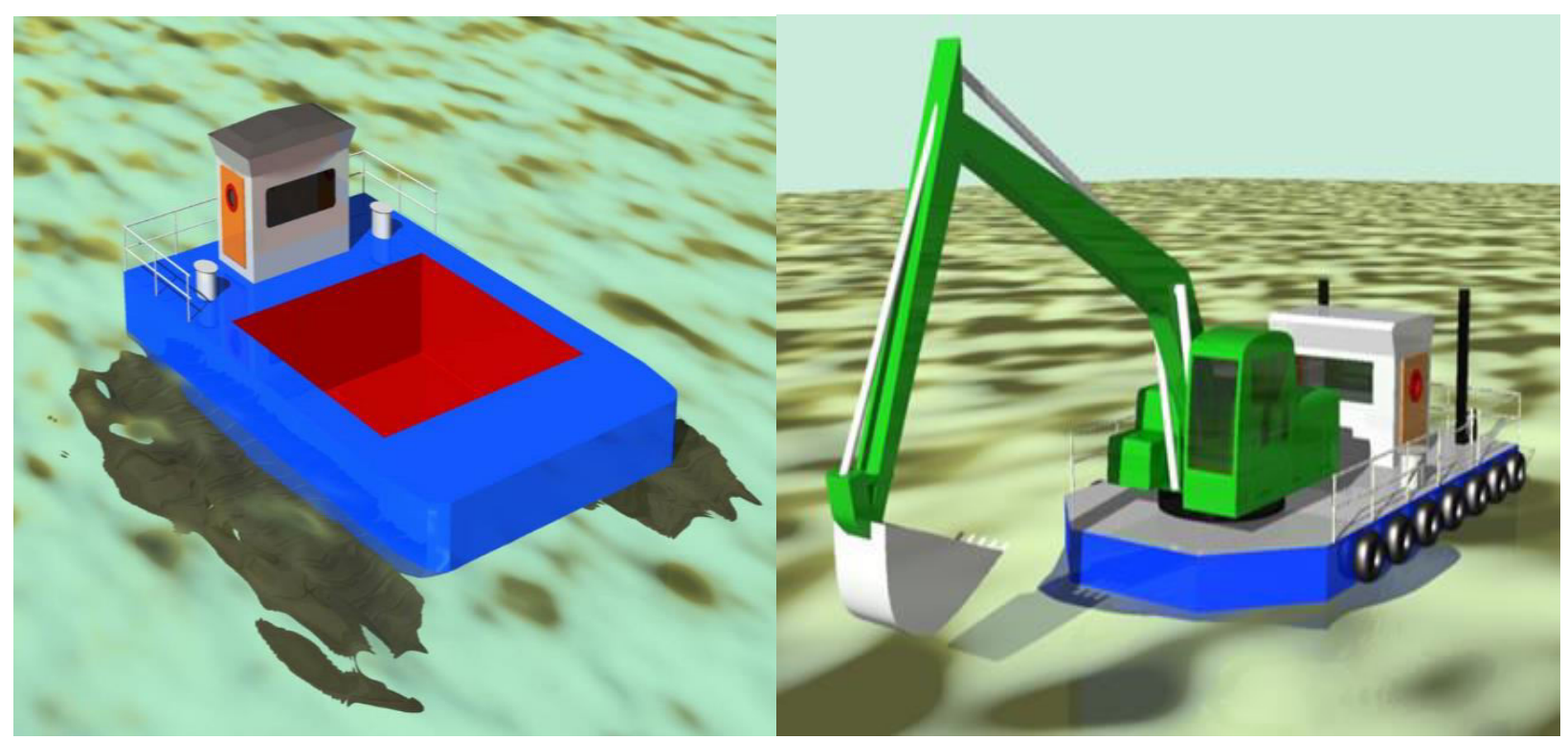

Gambar 4. 3 Dimensi.

\section{DAFTAR PUSTAKA}

[1]

Suprapto, "Permasalahan dan Solusi Pelestarian Sungai Porong," in Seminar Pelestarian Sungai Porong, 2016, pp. 1-5.

[2] M. R. . Jaelani, "Desain Dredger Berbasis Jalur Sungai Pada Program Tol Sungai Cikarang Bekasi Laut (CBL) - Tanjung Priok," J. POMITS, vol. 5, no. 2, 2016.

[3] N. Adiba, "Desain Trash Skimmer Amphibi-Boat Di Sungai
Ciliwung Jakarta," 2016.

[4] L. Prasetyo, "Desain Eco-friendly Boat Dengan Sumber Energi Hydrogen Fuel Cells Untuk Wisata Kali Mas Surabaya," Surabaya, 2015.

[5] H. Schneekluth and V. Betram, Ship Design for Efficiency and Economy, 2nd ed. Oxford, 1998. 